\title{
STUDI KESESUAIAN KUALITAS AIR UNTUK BUDIDAYA IKAN LELE DUMBO (Clarias gariepinus) DI KAMPUNG LAUK KABUPATEN BANDUNG
}

\section{STUDY OF WATER QUALITY SUITABILITY FOR CATFISH (Clarias gariepinus) CULTIVATION IN LAUK VILLAGES BANDUNG DISTRICT}

\author{
Perdana Putra Kelana ${ }^{*}$, Ujang Subhan², Ibnu Bangkit Biosina Suryadi², \\ Rangga Bayu Kusuma Haris ${ }^{1}$ \\ 1 Politeknik Kelautan dan Perikanan Dumai, Dumai, Indonesia \\ 2 Fakultas Perikanan dan IImu Kelautan Universitas Padjadjaran, Bandung, Indonesia \\ *Korespondensi: perdana.pk@politeknikkpdumai.ac.id (PP Kelana) \\ Diterima 7 Maret 2021 - Disetujui 28 Maret 2021
}

\begin{abstract}
ABSTRAK. Kampung lauk di Kabupaten Bandung merupakan salah satu upaya untuk meningkatkan produksi budidaya ikan lele dumbo (Clarias gariepinus). Tujuan studi ini untuk mengetahui kesesuaian kualitas air untuk budidaya ikan lele dumbo di Kabupaten Bandung. Metode pengambilan data yang digunakan pada studi ini adalah metode survey dengan teknik purposive sampling untuk penentuan titik pengamatan dan pengambilan contoh air. Studi ini dilakukan di 3 stasiun yang merupakan calon lokasi kampung lauk dengan 2 titik pengambilan contoh disetiap stasiun. Parameter yang diamati adalah suhu, oksigen terlarut, $\mathrm{pH}$ dan ammonia sesuai dengan parameter yang tertera pada SNI 01-6484.5:2002 Ikan Lele Dumbo (Clarias gariepinus) Kelas Pembesaran. Berdasarkan hasil pengamatan, nilai rata-rata seluruh parameter diseluruh stasiun sesuai dengan SNI 01-6484.5:2002, kecuali $\mathrm{pH}$ di stasiun 2. Berdasarkan hal tersebut, stasiun 1 dan 3 sesuai untuk budidaya ikan lele dumbo, stasiun 2 kurang sesuai.
\end{abstract}

KATA KUNCI: Bandung, Budidaya, Lele, Kesesuaian, Kualitas Air

ABSTRACT. Kampung lauk in Bandung district is one of the efforts to increase the production of catfish (Clarias gariepinus). The purpose of this study was to determine the suitability of water quality for catfish cultivation in Bandung district. The Method used in this study was a survey method with purposive sampling technique to determine the point of observation and water sampling. This study was carried out in 3 stations which were potential locations for the lauk village with 2 sampling points at each station. Parameters observed were temperature, dissolved oxygen, $\mathrm{pH}$ and ammonia in accordance with the parameters listed in SNI 01-6484.5: 2002 Catfish (Clarias gariepinus) Rearing Class. Based on observations, the average value of all parameters at all stations is in accordance with SNI 01-6484.5: 2002, except for pH at station 2. Based on this, stations 1 and 3 are suitable for catfish cultivation, station 2 is not suitable.

KEYWORDS: Bandung, cultivation, cat fish, suitability, water quality

\section{Pendahuluan}

Ikan lele dumbo (Clarias gariepinus) merupakan salah satu protein hewani yang banyak digemari oleh masyarakat Indonesia karena mudah didapat, harganya yang relatif murah dan memiliki kandungan protein tinggi serta lemak yang relatif lebih rendah. Kebutuhan sumber protein hewani khususnya ikan lele dumbo terus meningkat, sehingga perlu adanya inovasi agar produksi meningkat (Dhiba et al., 2019). Salah satu upaya inovasi dalam peningkatan produksi ikan lele dumbo adalah pendekatan pengembangan kampung tematik yaitu kampung lauk. Kampung lauk adalah wilayah yang memiliki potensi perikanan tinggi serta dapat meningkatkan pembangunan wilayah tersebut secara berkelanjutan dalam bidang perikanan (Dinas Perikanan dan Peternakan Kabupaten Bandung, 2017). 
Kabupaten Bandung merupakan salah satu daerah dengan potensi dan sumber daya yang mendukung dalam rangka pengembangan usaha perikanan berbasis potensi lokal yang mendorong peningkatan produksi ikan serta berkontribusi terhadap peningatan pendapatan masyarakat khususnya pelaku usaha budidaya ikan lele dumbo. Luas lahan potensi budidaya ikan di Kabupaten Bandung adalah 6.089,40 Ha dengan jumlah pembudidaya sebanyak 7.274 Rumah Tangga Perikanan dan produksi budidaya ikan lele sebesar 3.745,89 Ton. Dinaungi Dinas Pangan dan Perikanan telah terdapat unit pelayanan pembenihan ikan pemerintah dan unit kelembagaan perikanan yang dikelola kelompok perikanan yaitu UPT Pembenihan ikan sebanyak 1 unit dan Unit Pelayanan Pengembangan (UPP) perikanan 1 unit (Dinas Perikanan dan Peternakan Kabupaten Bandung, 2017).

Produksi budidaya perikanan dipengaruhi oleh tiga faktor yaitu kualitas benih, kualitas pakan, dan kualitas air (Ayuniar \& Hidayat, 2018). Benih yang berkualitas baik dapat di dukung oleh UPT Pembenihan ikan yang tersedia di wilayah Kabupaten Bandung. Pakan merupakan komponen biaya terbesar dalam budidaya ikan yang juga dapat mempengaruhi kualitas air. Kelayakan kualitas air perlu diidentifikasi sebagai Langkah awal melakukan kegiatan budidaya ikan. Beberapa studi yang pernah melakukan kajian kualitas air pada media budidaya ikan lele diantaranya adalah (Ayuniar \& Hidayat, 2018), (Dhiba et al., 2019) dan (UT et al., 2016), sedangkan kajian analisis kesesuain air tanah untuk budidaya ikan lele dumbo sudah dilakukan oleh (Suwarsito et al., 2020). Berdasarkan hal tersebut, studi yang membandingkan antara kualitas air yang akan digunakan untuk budidaya ikan lele dumbo dengan SNI 01-6484.5:2002 Ikan Lele Dumbo (Clarias gariepinus) Kelas Pembesaran perlu dilakukan. Tujuan studi ini untuk mengetahui kesesuaian kualitas air untuk budidaya ikan lele dumbo di kampung lauk Kabupaten Bandung.

\section{Bahan dan Metode}

\subsection{Waktu dan Tempat Studi}

Studi ini dilakukan selama 1 bulan pada Agustus 2017. Studi ini berlangsung pada 3 lokasi yaitu Stasiun 1 di Desa Lampegan Kecamatan Ibun, Stasiun 2 Desa Ciapus Kecamatan Banjaran dan Stasiun 3 Desa Tanjung Wangi Kecamatan Pacet. Lokasi tersebut dipilih karena telah menjadi prioritas Pemerintah Daerah Kabupaten Bandung sebagai kampung tematik dengan produksi hasil budidaya ikan.

\subsection{Peralatan Studi}

Peralatan yang digunakan pada studi ini adalah peralatan untuk mengukur, mengambil dan membawa contoh air dari setiap lokasi. Adapun peralatan tersebut tersaji pada Tabel 1.

Tabel 1. Peralatan Pengambilan Data

\begin{tabular}{ll}
\hline & \multicolumn{1}{c}{ Alat } \\
\hline Thermo Meter & Mengukur suhu air \\
DO Meter & Mengukur kadar oksigen terlarut \\
pH Meter & Mengukur pH air \\
Botol Contoh Air & Mengambil contoh air \\
Cool Box & Menyimpan botol contoh air \\
Kertas Label & Menandai botol contoh air \\
Ice Pack & Menjaga suhu di dalam cool box \\
Pensil & Mencatat dan menulis \\
Buku catatan & Mencatat dan menulis \\
\hline
\end{tabular}




\subsection{Metode Pengambilan Data}

Metode pengambilan data yang digunakan pada studi ini adalah metode survey dengan teknik purposive sampling untuk penentuan titik pengamatan dan pengambilan contoh air. Setiap stasiun terdapat 2 titik pengamatan dan pengambilan contoh air yaitu pada sumber air dan badan kolam. Parameter kualitas air yang diamati secara langsung (Insitu) adalah suhu, oksigen terlarut (Dissolved Oxygen) dan $\mathrm{pH}$ air. Contoh air diambil menggunakan botol yang kemudian diberi label sesuai dengan lokasi dan titik pengamatan. Botol berlebel tersebut dimasukan ke dalam cool box yang sudah diberi ice pack, lalu dikirim ke Laboratorium MSP Fakultas Perikanan dan Ilmu Kelautan Universitas Padjadjaran. Adapun parameter yang diamati pada laboratorium tersebut adalah Amonia $\left(\mathrm{NH}_{3}\right)$.

\subsection{Metode Pengolahan Data}

Analisis data yang digunakan pada studi ini adalah analisis deskriptif. Data kualitas air yang diamati secara langsung maupun di laboratorium kemudian dibandingkan dengan SNI 01-6484.5:2002 Ikan Lele Dumbo (Clarias gariepinus) Kelas Pembesaran di Kolam sebagai acuan standar kualitas air untuk melakukan budidaya lele. Hasil perbandingan tersebut kemudian dibahas secara deskriptif untuk memberikan hasil yang lebih terperinci dan mudah dipahami.

\section{Hasil dan Pembahasan}

Parameter kualitas air yang diamati pada studi ini adalah suhu, oksigen terlarut, $\mathrm{pH}$ dan ammonia. Parameter tersebut merupakan parameter yang disebutkan dalam SNI 01-6484.5:2002 mengenai Ikan Lele Dumbo (Clarias gariepinus) Kelas Pembesaran di Kolam. Kualitas air suatu perairan perlu dibandingkan dengan standar kelayakan yang ada, karena itu setiap kegiatan yang dilakukan di lingkungan perairan memiliki nilai persyaratan yang berbeda, sesuai dengan peruntukannya (Koniyo, 2020). Nilai rata-rata parameter kualitas air di lokasi studi tersaji pada Tabel 2.

Tabel 2. Hasil Pengamatan Kualitas Air di Lokasi Studi

\begin{tabular}{|l|r|r|r|r|r|r|r|}
\hline \multirow{2}{*}{ Parameter } & \multicolumn{2}{|c|}{ Stasiun 1 } & \multicolumn{2}{c|}{ Stasiun 2 } & \multicolumn{2}{c|}{ Stasiun 3 } & Acuan \\
\cline { 2 - 8 } & Sumber Air & \multicolumn{1}{c|}{ Kolam } & Sumber Air & \multicolumn{1}{c|}{ Kolam } & Sumber Air & \multicolumn{1}{c|}{ Kolam } & SNI 01-6484.5:2002 \\
\hline Suhu $\left({ }^{\circ} \mathrm{C}\right)$ & $28,5 \pm 1,3$ & $28,3 \pm 1,7$ & $26,4 \pm 1,7$ & $26,5 \pm 2,1$ & $28,5 \pm 1,4$ & $28,6 \pm 1,9$ & $25-30$ \\
\hline $\mathrm{DO}(\mathrm{mg} / \mathrm{l})$ & $7,5 \pm 0,5$ & $7,6 \pm 0,6$ & $7,6 \pm 0,4$ & $7,5 \pm 0,3$ & $7,6 \pm 0,4$ & $7,5 \pm 0,5$ & $>4$ \\
\hline $\mathrm{pH}$ & $7 \pm 0,5$ & $7,1 \pm 0,4$ & $5 \pm 0,4$ & $6 \pm 0,6$ & $7,7 \pm 0,3$ & $7,1 \pm 0,4$ & $6,5-8,5$ \\
\hline Amonia $(\mathrm{mg} / \mathrm{l})$ & $<0,01$ & $<0,01$ & $<0,01$ & $<0,01$ & $<0,01$ & $<0,01$ & $<0,01$ \\
\hline
\end{tabular}

Suhu air rata-rata tertinggi pada sumber air terdapat di stasiun 3 dengan nilai $28,5^{\circ} \mathrm{C} \pm 1,4^{\circ} \mathrm{C}$ dan terendah di Stasiun 1 dengan nilai $26,4^{\circ} \mathrm{C} \pm 1,7^{\circ} \mathrm{C}$. Suhu air rata-rata tertinggi pada kolam terdapat di stasiun 3 dengan nilai $28,6^{\circ} \mathrm{C} \pm 1,9^{\circ} \mathrm{C}$ dan terendah di Stasiun 1 dengan nilai 26,5 $\pm 2,1$ (Gambar 1 ). Titik pengamatan kualitas air di sumber air pada setiap lokasi merupakan aliran sungai yang di belokan untuk masuk kedalam kolam. Nilai rata-rata suhu di stasiun 3 dikarenakan baik lokasi sumber air maupun kolam relatif terbuka dan terpapar sinar matahari secara langsung, sedangkan lokasi sumber air dan kolam di stasiun 1 terlindungi oleh kanopi pohon, sehingga paparan sinar matahari relatif lebih sedikit dan suhu menjadi lebih rendah dibandingkan dengan stasiun 1 dan 3. Paparan sinar matahari merupakan salah satu faktor yang mempengaruhi suhu selain letak geografis dan musim (Yumame et al., 2013). Suhu pada seluruh stasiun sesuai dengan SNI 01-6484.5:2002. Suhu merupakan parameter penting dan menjadi controling factor yang dapat mempengaruhi sintasan organisme perairan, khususnya ikan, karena ikan merupakan mahluk hidup poikilothermal yang proses metabolisme dan kekebalan tubuhnya bergantung pada suhu lingkungan (Ayuniar \& Hidayat, 2018). 


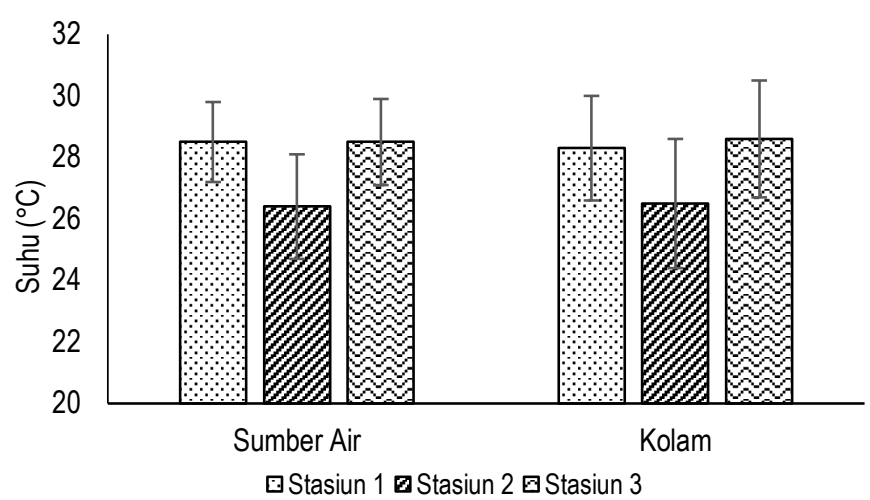

Gambar 1. Niali Rata-rata Suhu di Lokasi Studi

Kandungan oksigen terlarut dalam air berpengaruh terhadap respirasi dan metabolisme serta sintasan biota perairan khususnya ikan (Suwarsito et al., 2020). Nilai rata-rata oksigen terlarut di seluruh lokasi studi baik pada sumber air maupun kolam relatif tidak berbeda (Gambar 2). Kandungan oksigen yang cenderung tidak berfluktuasi karena sirkulasi air yang baik dan belum adanya pemeliharaan ikan pada kolam di seluruh stasiun. Sirkulasi air yang baik dapat menjaga kestabilan nilai kandungan oksigen terlarut (Aisya et al., 2017). Nilai rata-rata oksigen terlarut lebih tinggi dibandingkan dengan SNI 016484.5:2002. Kelebihan oksigen akan dibutuhkan sejalan dengan pertumbuhan ikan, selain itu kelebihan oksigen dapat dimanfaatkan oleh mikroba dalam proses dekomposisi bahan organik (Maniani et al., 2016).

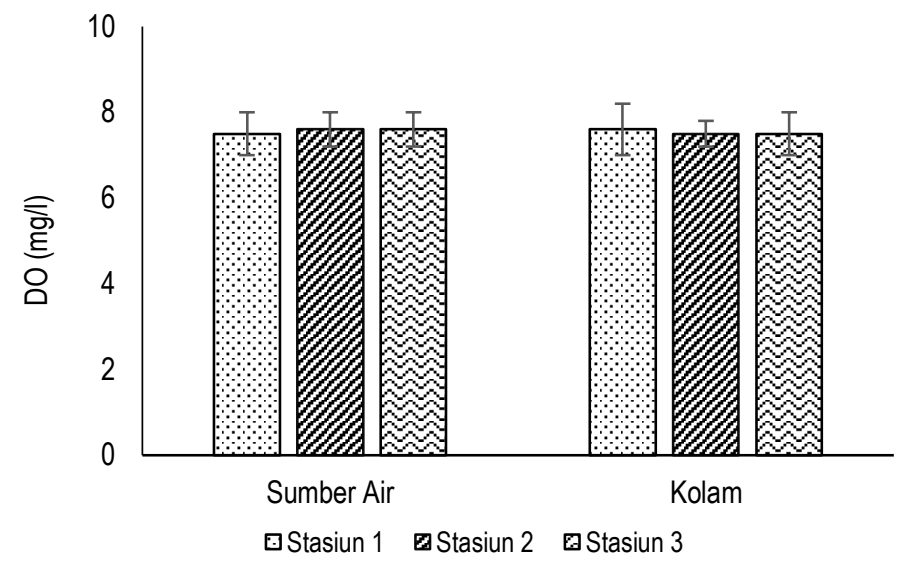

\section{Gambar 2. Nilai Rata-rata Kandungan Oksigen Terlarut di Lokasi Studi}

Hasil pengamatan selama studi menunjukan nilai rata-rata $\mathrm{pH}$ tertinggi terdapat di sumber air pada stasiun 3 dengan nilai $7,7 \pm 0,3$, sedangkan nilai rata-rata $\mathrm{pH}$ terendah terdapat di sumber air pada stasiun 2 dengan nilai $5 \pm 0,4$ (Gambar 3 ). Kisaran niali rata-rata pH pada stasiun 1 dan 3 berada pada kisaran netral dan sesuai dengan SNI 01-6484.5:2002. Tinggi rendahnya nilai pH di suatu perairan dapat disebabkan oleh fluktuasi bahan organik dan meningkatnya konsentrasi $\mathrm{CO}_{2}$ karena aktivitas mikroba dalam menguraikan bahan organic tersebut (Maniani et al., 2016). Gas karbondioksida $\left(\mathrm{CO}_{2}\right)$ di perairan dapat membentuk asam karbonat $\left(\mathrm{H}_{2} \mathrm{CO}_{3}\right)$ yang dapat merubah kondisi perairan menjadi lebih asam (Efendi, 2003). Nilai rata-rata $\mathrm{pH}$ di stasiun 2 cenderung asam dan tidak sesuai dengan SNI 016484.5:2002. Niali pH rendah (keasaman yang tinggi) berpengaruh terhadap turunnya niali kandungan oksigen terlarut, akibatnya konsumsi oksigen oleh organisme perairan menurun, aktivitas pernapasan naik dan selera makan akan berkurang (Tokah et al., 2017). Perlakuan yang dapat dilakukan untuk meningkatkan nilai $\mathrm{pH}$ yang sesuai dengan prinsip biosekuriti adalah dengan menambahkan kapur ataupun air kapur kedalam media pemeliharaan (Pratiwi et al., 2020). 
Aurelia Journal, Vol. 2 (2): $159-164$

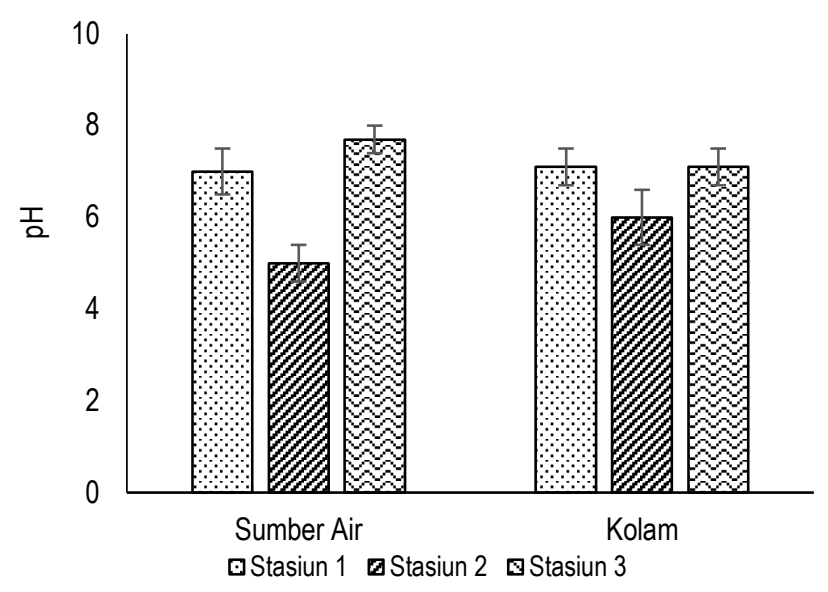

Gambar 3. Nilai Rata-rata pH di Lokasi Studi

Nilai rata-rata kandungan ammonia diseluruh stasiun menunjukan nilai kurang dari 0,01 $\mathrm{mg} / \mathrm{l}$ dan nilai tersebut sesuai dengan SNI 01-6484.5:2002. Kandungan ammonia dan oksigen terlarut di perairan memiliki hubungan berbanding terbalik, apabila ammonia meningkat maka kadar oksigen terlarut menjadi rendah, Keberadaan ammonia dalam air juga dapat menyebabkan berkurangnya daya ikat oksigen oleh butir-butir darah, hal ini akan menyebabkan nafsu makan ikan menurun dan menghambat pertumbuhan ikan (Tokah et al., 2017). Peningkatan pH dan suhu dapat meningkatkan toksisitas ammonia. Pengaruh pH pada toksisitas ammonia telah dikonfirmasi oleh penelitian pada ikan lele belang bahwa toksisitas $\mathrm{NH} 3$ meningkat ketika pH meningkat (Phuong et al., 2014). Amonia beracun bagi ikan karena bila di perairan terlalu jenuh dengan ammonia, ikan tidak dapat melepaskan amonia dari berupa urine atau feses dari tubuh sehingga ikan teracuni ammonia dari dalam (Pratiwi et al., 2020). Sumber ammonia di perairan dipengaruhi oleh adanya proses pemecahan nitrogen organik dan anorganik yang terdapat di dalam tanah dan air yang berasal dari dekomposisi bahan organik termasuk diantaranya hasil ekskresi biota (feses) dan sisa pakan yang tidak termakan (Efendi, 2003). Akumulasi ammonia pada media budidaya merupakan salah satu penyebab penurunan kualitas perairan yang dapat berakibat pada kegagalan produksi budidaya ikan (Ayuniar \& Hidayat, 2018).

\section{Kesimpulan}

Stasiun 1 dan 3 merupakan lokasi yang sesuai untuk dilakukan budidaya ikan lele karena seluruh nialai rata-rata setiap parameter yang diamatai sesuai dengan nilai parameter yang terdapat pada SNI 01-6484.5:2002 Ikan Lele Dumbo (Clarias gariepinus) Kelas Pembesaran di Kolam. Sedangakan Stasiun 3 kurang sesuai untuk dilakukan budidaya ikan lele karena nilai rata-rata $\mathrm{pH}$ saat pengamatan dibawah nilai pH pada pada SNI 01-6484.5:2002. Hal tersebut dapat diatasi dengan meberikan perlakuan pengapuran pada kolam budidaya guna meningkatkan dan menjaga kestabilan nilai pH.

\section{Daftar Pustaka}

Aisya, W. P., Hastuti, sri, \& Subandiyono. (2017). Performa Produksi lkan Lele (Clarias Gariepinus) yang dipelihara Dalam Sistem Budidaya Berbeda. Journal of Aquaculture Management and Technology, 4(4), 51-60. http://ejournal-s1.undip.ac.id/index.php/jamt\%0APERFORMA

Ayuniar, L. N., \& Hidayat, J. W. (2018). Analisis Kualitas Fisika dan Kimia Air di Kawasan Budidaya Perikanan Kabupaten Majalengka. Jurnal EnviScience, 2(2), 68-74.

Dhiba, A. A. F., Syam, H., \& Ernawati. (2019). Analisis Kualitas Air Pada Kolam Pendederan Ikan Lele Dumbo (Clarias Gariepinus) dengan Penambahan Tepung Daun Singkong (Manihot Utillisima) Sebagai Pakan Buatan. Jurnal Pendidikan Teknologi Pertanian, 5(1), 131-144.

Dinas Perikanan dan Peternakan Kabupaten Bandung. (2017). Penyusunan Studi Kelayakan (Feasibility 
Study) Pembangunan Kampung Lauk Di Kabupaten Bandung.

Efendi, H. (2003). Telaah Kualitas Air Bagi Pengelolaan Sumber Daya Dan Lingkungan Perikanan. Kanisius.

Koniyo, Y. (2020). Analisis Kualitas Air pada Lokasi Budidaya Ikan Air Tawar di Kecamatan Suwawa Tengah. Jurnal Technopreneur (JTech), 8(1), 52-58. https://doi.org/10.30869/jtech.v8i1.527

Maniani, A. A., Tuhumury, R. A. N., \& Sari, A. (2016). Pengaruh perbedaan filterisasi berbahan alami dan buatan (sintetis) pada kualitas air budidaya lele sangkuriang (clarias $s p$.) Dengan sistem resirkulasi tertutup. The Journal OfFisheries Development, 2(2), 17-34.

Phuong, N., Y, L. H., Phu, T. Q., \& Cong, N. . (2014). Effects of ph on toxicity of tan to the striped catfish (Pangasianodon hypophthalmus) Gingerlings. Science Journal of Can Tho University, 30, 6471.

Pratiwi, R., Hidayat, K. W., \& Sumitro, S. (2020). Production performance of catfish (Clarias gariepinus burchell, 1822) cultured with added probiotic Bacillus sp. ON BIOFLOC TECHNOLOGY. Journal of Aquaculture and Fish Health, 9(3), 274. https://doi.org/10.20473/jafh.v9i3.16280

Suwarsito, Kamila, A. H. Z., \& Purbomartono, C. (2020). Kajian Kesesuaian Kualitas Air Tanah Untuk Budidaya Ikan Lele (Clarias gariepinus) di Desa Karangsari Kecamatan Kembaran Kabupaten Banyumas. Sainteks, 17(1), 1-6. https://doi.org/10.30595/sainteks.v17i1.8414

Tokah, C., Undap, S. L., \& Longdong, S. N. J. (2017). Kajian Kualitas Air Pada Area Budidaya Kurungan Jaring Tancap (KJT) di Danau Tutud Desa Tombatu Tiga Kecamatan Tombatu Kabupaten Minahasa Tenggara. Budidaya Perairan, 5(1), 1-11.

UT, V. N., Giang, H. T., Phu, T. Q., Morales, J., \& Phuong, N. (2016). Assessment of Water Quality in Catfish (Pangasianodon hypophthalmus) production systems in the mekong delta. Can Tho University Journal of Science, 03, 71. https://doi.org/10.22144/ctu.jen.2016.026

Yumame, R. Y., Rompas, R., \& Pangemanan, P. N. . (2013). Kelayakan kualitas air kolam di lokasi Pariwisata Embung Klamalu Kabupaten Sorong Provinsi Papua Barat. Budidaya perairan, 1(3), 5662. https://doi.org/10.35800/bdp.1.3.2013.2735 